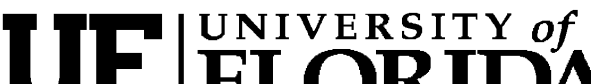 FLORIDA \\ IFAS Extension
}

\section{Olive Fruit Fly, Bactrocera oleae (Rossi) (Insecta: Diptera: Tephritidae) ${ }^{1}$}

H. V. Weems and J. L. Nation ${ }^{2}$

\section{Introduction}

The olive fruit fly, Bactrocera oleae (Rossi) (formerly Dacus oleae), is a serious pest of olives in most of the countries around the Mediterranean sea. The larvae are monophagous, and feed exclusively on olive fruits. Adults feed on nectar, honey dew, and other opportunistic sources of liquid or semi-liquid food. The damage caused by tunneling of larvae in the fruit results in about 30 percent loss of the olive crop in Mediterranean countries, and especially in Greece and Italy where large commercial production occurs.

The olive fruit fly is generally a serious pest of cultivated olives throughout its range. It was detected in California in October, 1998 in the Los Angeles area, and spread to the rest of southern California (1999), the Central Valley (2000) and to Marin, Napa, Sonoma, Solano (2001), Shasta, El Dorado and Lake (2002) counties (Vossen et al. 2206). It is now found in all olive growing areas of the state (Zalom, Van Steenwyk, Burrack and Johnson 2009).
Olives are grown commercially in California, for the fruit, on a limited scale and are grown also as ornamentals. In Florida, olive trees are slow-growing evergreens that may be grown as ornamentals, but have no commercial application in relation to the fruit. Use of olive trees as ornamentals is increasing in Florida, and fruit from these trees probably could support olive fruit fly development. Thus, state and federal regulatory agencies should continue to maintain vigilance against introduction of the olive fruit fly. Larvae and pupae are intercepted frequently in olives from the Mediterranean region, and occasionally adults have been taken along with larvae and pupae.

\section{Distribution}

Mediterranean basin, northern, eastern and southern Africa, Canary Islands, India, western Asia, and apparently wherever olives (the genus Olea) occur in the Eastern Hemisphere.

In the Western Hemisphere, it is currently restricted to California, and Baja California, Mexico (Rice 2000).

1. This document is EENY-113 (IN270) (originally published as DPI Entomology Circular No. 44), one of a series of Featured Creatures from the Entomology and Nematology Department, Florida Cooperative Extension Service, Institute of Food and Agricultural Sciences, University of Florida. Published: September 1999. Revised: July 2009. This document is also available on Featured Creatures website at http://entomology.ifas.ufl.edu/creatures. Please visit the EDIS website at http://edis.ifas.ufl.edu.

2. H. V. Weems, Florida Department of Agriculture and Consumer Services, Division of Plant Industry, Gainesville, FL and J. L. Nation, professor, Entomology and Nematology Department, University of Florida, Gainesville, FL. 


\section{Identification}

Immature stages are similar in appearance to those of other tephritid fruit flies, especially Bactrocera spp. Phillips gives a detailed, illustrated description of the larva.

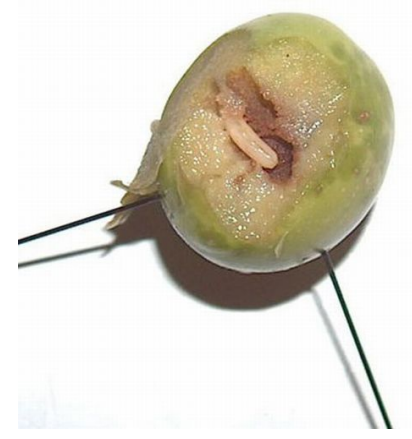

Figure 1. Third instar larva of the olive fruit fly, Bactrocera oleae (Rossi). Credits: Giancarlo Dess, Istituto Professionale Statale per l'Agricoltura e l'Ambiente "Cettolini" di Cagliari

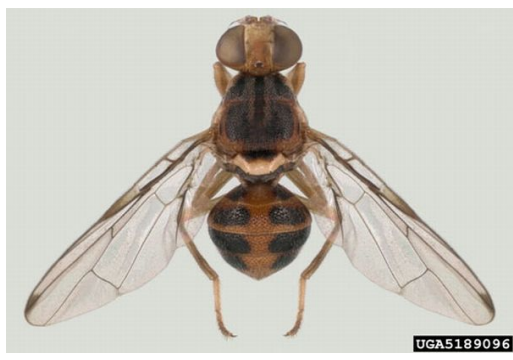

Figure 2. Adult olive fruit fly, Bactrocera oleae (Rossi). Credits: Natasha Wright, Florida Department of Agriculture and Consumer Services

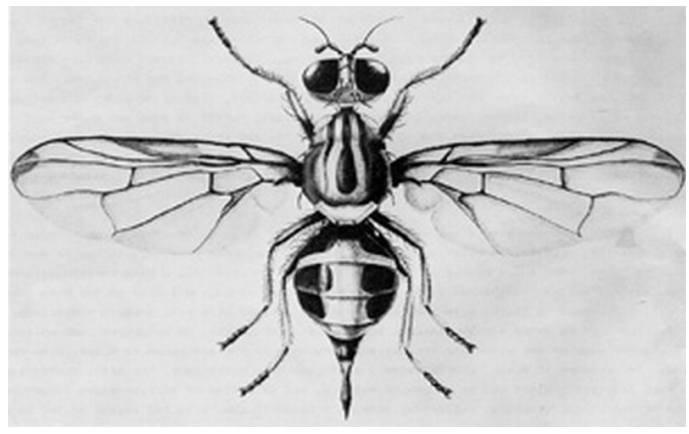

Figure 3. Adult female olive fruit fly Credits: James Castner, University of Florida

The olive fruit fly is one of the smaller species in the genus. The adult female is approximately $5 \mathrm{~mm}$ long, and has a wing expanse of approximately 10 $\mathrm{mm}$. The wings are mostly transparent and marked with brown, including a spot at the wing tips. The thorax is black, with a silvery pubescence dorsal surface stripped with three narrow parallel black lines. The humeri, or shoulders, and an area above and below the base of the wings are yellow. The inner portion of the scutellum is black, and the posterior portion is yellow. The abdomen is black, covered with a scattered gray pubescence. The basal segments are marked with pale transverse bands and an irregular parallel bar or blotch of reddish-brown occupying the center of the apical segments. The terminal segment is reddish-yellow. The sheath of the ovipositor is black, with the ovipositor reddish in color.

\section{Life History and Habits}

In the Mediterranean region, two to five generations of flies occur yearly. The winter is spent in the pupal stage several $\mathrm{cm}$ below the soil and leaf litter, and adult flies emerge from March to May, depending upon the latitude and temperature. Under summer conditions, a preoviposition period of six to ten days elapses before mating, with longer time required earlier when temperatures are not as high. During the preoviposition period the female is maturing the ovary and a first set of eggs. Beginning in June females actively seek and oviposit in early maturing olive fruits. From 10 to 12 eggs may be laid daily, usually one per olive fruit, and about 200 to 250 are laid in a lifetime. The female punctures the fruit with the ovipositor and deposits an egg beneath the skin.

In the mild, coastal areas of California, the adult flies are active all year. Eggs and maggots may be found all year in fruit left on the ground or on the trees. In the inland areas of California, the adult flies emerge from March through May and attack olives remaining on trees from the previous season. During early summer (June) as temperatures and day length increase and few mature fruit remain on trees, female flies do not lay eggs. However, the adults remain active and may disperse to other crops, such as citrus orchards or vineyards. As a new olive crop develops (late June to the beginning of July), females are attracted to the fruit and begin to lay eggs. Eggs are laid just under the fruit's skin, often creating a dimple or brown spot. Multiple generations occur throughout summer and fall. (Zalom, Van Steenwyk, Burrack and Johnson 2009) 
The legless larva (maggot) feeds upon the fruit tissue, causing the fruit to drop off the tree. The egg, larval, and pupal stages last 2 to 4, 10 to 14, and about 10 days, respectively, in summer in Yugoslavia. Duration of the life cycle varies from one to six or seven months. Male flies produce an auditory stridulatory sound or signal during courtship. Courtship and mating occur at dusk, near the end of the daylight period.

Females of the olive fruit fly produce a multicomponent pheromone, and are the only tephritid females known to produce a sex pheromone. Males produce the pheromone in other tephritids that have been studied. The major component of the pheromone is 1,7-dioxaspiro[5.5] undecane and it is a relatively long-range attractant for males. Male flies also produce this compound, and attract males, but females are not attracted to the compound from either sex. Feral females likely mate several times during their lifetime.

\section{Hosts}

\section{Olives-(Olea spp.)}

\section{Management Procedures}

In the Eastern Hemisphere, insecticides are used in bait-sprays or as sprays from the air to control the olive fruit fly. More environmentally benign techniques that are being tested or used in limited areas are use of radiation sterilized males and pheromones. Both sexes can be sterilized with 8 to 12 $\mathrm{krad}$ (80 to $120 \mathrm{~Gy}$ radiation) when late pupae are exposed to the irradiation. Synthesis of 1,5,7-trioxaspiro[5.5] undecane, an analog of the major pheromone component, has been synthesized and tested, and under optimal conditions it was as attractive as the natural compound, but it did not last as long in traps as the natural material. Small plywood rectangles dipped in $0.1 \%$ (a.i.) aqueous solution of deltamethrin for 15 minutes and added to bait stations containing either sex pheromone or ammonium bicarbonate, a food attractant, gave cost-effective control in a large test orchard.

In California, management depends on bait sprays, trapping of adult flies, harvest timing, fruit sanitation after harvest, and biological control (Van Steenwky et al. 2003).

A recent (2008) introduction of a hymenopteran parasitoid, Psyttalia cf. concolor, from Kenya has raised hopes for effective biologicial control of the olive fruit fly. The wasp appears to be a more effective natural enemy than other olive fly parasitoids brought to California in the early 2000s. Early results showed that the wasp's parasitism rate was variable in some hot, dry, inland groves, where the olive fruit fly is sparse, but in a coastal orchard heavily infested with the flies, parasitism was very high (Wood 2009).

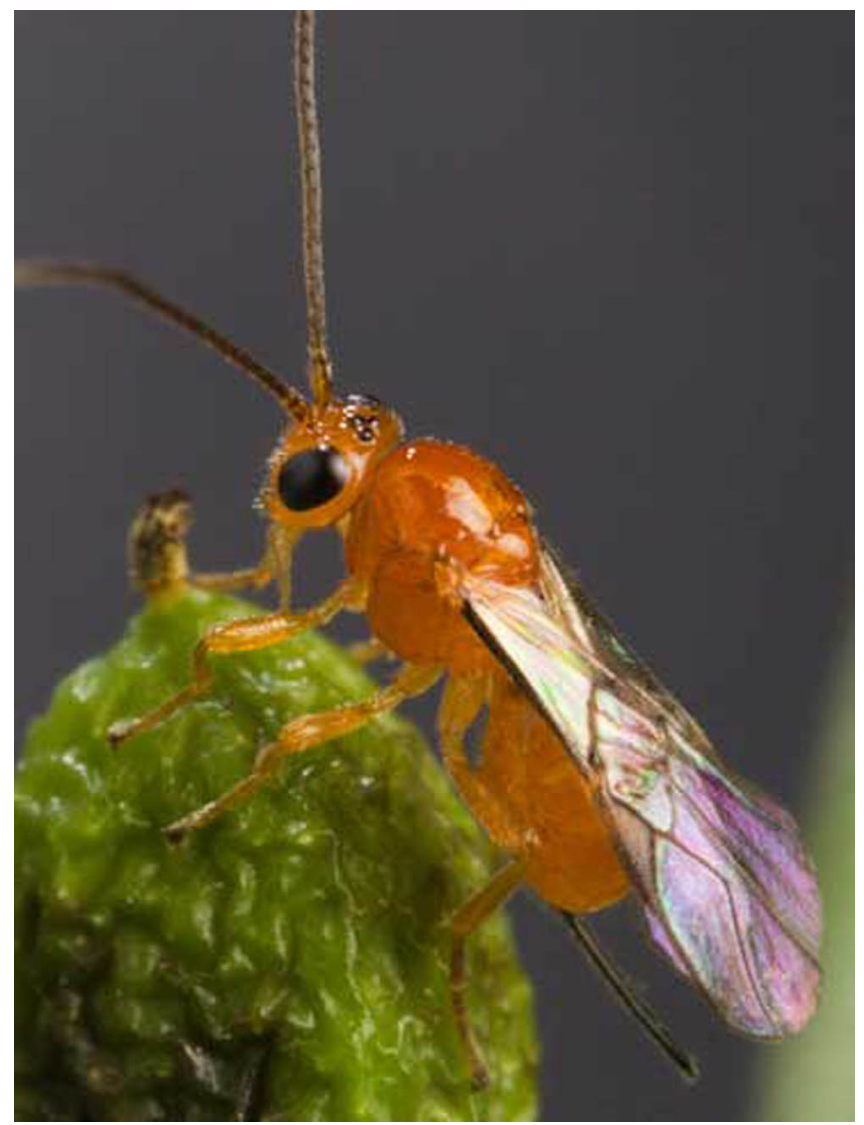

Figure 4. The parasitoid Psyttalia cf. concolor was discovered in Kenya, reared in a laboratory in Guatemala, and imported into California for biological control of olive fruit fly. Credits: Peggy Greb, US

\section{Selected References}

- Christenson LD. 1963. Tropical fruit-fly menace. Publ. 4557 from the Smithsonian Report for 1962. p. 441-448. 
- Christenson LD, Foote RH. 1960. Biology of fruit flies. Annual Review of Entomology 5: 171-192.

- Ebeling WW. 1959. Subtropical Fruit Pests. University of California, Division of Agricultural Science. 436 p.

- Economopoulos AP. 1972. Sexual competitiveness of g-ray sterilized males of Dacus oleae. Mating frequency of artificially reared and wild females. Environmental Entomology 1: 490-497.

- Economopoulos AP, Giannakakis A, Tzanakakis ME, Voyadjoglou AV. 1971. Reproductive behavior and physiology of the olive fruit fly. 1. Anatomy of the adult rectum and odors emitted by adults. Annals of the Entomological Society of America 64: 1112-1116.

- Froggatt WW. 1909. Report on parasitic and injurious insects. 1907-1908. New South Wales Department of Agriculture. $115 \mathrm{p}$.

- Haniotakis GE, Kozyrakis K, Bonatsos C. 1986. Control of the olive fruit fly, Dacus oleae Gmel. (Diptera, Tephritidae) by mass trapping: Pilot scale feasibility study. Journal of Applied Entomology 101: 343-352.

- Haniotakis GE, Mavraganis VG, Ragoussis V. 1989. 1,5,7-Trioxaspiro[5.5]undecane, a pheromone analog with high biological activity for the olive fruit fly, Dacus oleae. Journal of Chemical Ecology 15: 1057-1065.

- Hendel F. 1927. Trypetidae. Stuttgart: E. Schweizerbart'sche Verlagsbuchhandlung. 221 p.

- Mazomenos BA. 1983. Biosynthesis of a Sex Pheromone of the Olive Fruit Fly Dacus oleae Gmel. PhD Dissertation. Rijksuniversiteit Gent, The Netherlands. 137 p.

- Oakley RG. 1950, January 30. Fruit flies (Tephritidae). Manual of foreign plant pests for fruit flies, Part 3. p. 167-246. (unpublished)
- Phillips VT. 1946. The biology and identification of trypetid larvae (Diptera: Trypetidae). Memoirs of the American Entomological Society 12: 1-161.

- Rice R. (July 2000). Bionomics of the olive fruit fly, Bactrocera (Dacus) olea. University of California Plant Protection Quarterly. pp 1-5. http://www.uckac.edu/ppq/PDF/00July.pdf (27 July 2009).

- Varela L, Vossen P. (September 2006). Olive fruit fly. University of California Cooperative Extension - Sonoma County. http://cesonoma.ucdavis.edu/files/27231.pdf (30 September 2010).

- Wood M. (February 2009). Can small foe foil olive fruit fly? USDA News \& Events. http://www.ars.usda.gov/is/AR/archive/feb09/ olive0209.htm (10 March 2009).

- Zalom FG, Vossen PM, Van Steenwyk RA. (January 2009). Olive fruit fly. University of California Pest Management Guidelines. http://www.ipm.ucdavis.edu/PMG/ r583301311.html (9 March 2009).

- Zalom FG, Van Steenwyk RA, Burrack HJ, Johnson MW. (February 2009). Olive fruit fly. University of California Pests in Gardens and Landscapes. http://www.ipm.ucdavis.edu/PMG/PESTNOTES/ pn74112.html (9 March 2009). 